\title{
PIONEER
}

VOLUME 11, Issue 2, December 2019: 68 - 76

\section{A SOCIOLINGUISTIC STUDY ON CODE SWITCHING USED BY SOCIETY IN BATURAJA VILLAGE}

\author{
Wardhatun Nahdoh \\ Bumigora University \\ wardhatunnahdoh@gmail.com \\ Wiya suktiningsih \\ Bumigora University \\ wiyasukti@gmail.com
}

Agus Syahid

Bumigora University

deragus@gmail.com

\begin{abstract}
This study discusses code switching used by society in Baturaja village. This study aims to determine the types of code switching used by Baturaja society and the factors that determine code switching. The theory used in this research is sociolinguistic theory about code switching, types of code switching, factor of code switching. This research is descriptive qualitative. The data collection instruments consist of observation, recording, transcribing data, interviews, and taking notes. Based on the analysis, it was found that there are two types of code switching used by Baturaja society. the first type is internal code switching, the transition of language from local languages to national languages or vice versa. The second type is external code switching, namely the transfer of languages from national languages to international languages or vice versa. There are several factors that affect code switching: a) speaker, b) listener or interlocutor, c) presence of a third person, d) change in situation, and e) change the topic.
\end{abstract}

Keywords: Baturaja society, code switching

\section{INTRODUCTION}

Humans are social creatures who cannot live alone. Humans are individuals who are greatly influenced by the social environment, even they cannot develop according to the dignity of their humanity without living in a social environment. The human social environment is inseparable from communication. Communication is a process by which information is exchange between individuals through common system of symbols, sign, or behavior. In each communication there must be three components such as the party that communicates (sender or recipient of information), information communicated, tools used in communication (language). There are two kinds of language 
communication, namely direct communication and two-way communication. In communication in the same direction, the sender remains the sender, and the recipient remains the recipient. Whereas two-way communication that is alternately the sender can be the recipient, and the recipient can be the sender.

Language according to Owen in Setiawan (2006: 1) can be defined as socially shared of those symbol and rules governed combination of those symbol. Language itself is productive and dynamic, productive means language with a limited number of elements but can be made of almost unlimited speech units. Whereas the dynamic language means that the language is inseparable from the possibility of changes that can change at any time. Language is a very important tool for humans to communicate each other. The science of learning languages scientifically is linguistics.

Linguistic is the study of language as the object of study. Linguistics is often also called general linguistics, meaning linguistics does not only study a language, but examines the ins and outs of common language. Based on the object of study, linguistics is divided into two, namely micro linguistics and macro linguistics. Micro linguistics directs its study on the internal structure of language in terms of language structure, and applicable rules. There are several subdivisions in micro linguistics namely phonology, morphology, syntax, semantic, and lexicology. While macro linguistics investigates language in relation to factors outside of language. There are several courses in macro linguistics namely sociolinguistics, psycholinguistics, anthropolinguistics, philology, philosophy of language, dialectology, stylistics, and neourolinguistics.

Based on the relationship between language and language users in the community, this study uses sociolinguistic studies. Sociolinguistics is an interdisciplinary science between sociology and linguistics, two fields of empirical science that have very close ties. According to Booij, Kersten and Verkuyl 1975: 139), sociolinguistiek is subdiscipline of van de taalkunde, die bestudert welke social factoren een spelen in het taal gebruik er welke taal spelt in het social verkeer (sociolinguistics is a subdiscipline of linguistics that studies social factors play a role in the use of language and social interaction). Sociolinguistic explains how the use of language in certain aspects or social aspects. Language as an object in sociolinguistics, language is not seen or approached as a language, as is done in general linguistics, but seen as a means of communication and interaction in human society. Every human activity starts 
from waking up to sleeping again of course use language, even when the baby is born until he is an adult, he uses it for language in a self-maturing processor.

Language competence by each individual must be different. There are those who master two languages or called bilingual, there are also those who master more than two languages or multilingual. Mastery of language certainly affects humans in communicating, for example in interacting each other, someone often changes or diverts the language he uses. When A speaks to B using Indonesian, then C comes and speaks using Sasak language. A and B immediately change the language they use to Sasak language. This process in sociolinguistics is called code switching. Code switching according to Appel (1976: 79) is a symptom of switching language use due to changing situations. Code switching is divided into two, namely internal code switching and external code switching. Internal code switching is the transition of languages from regional languages to national languages and vice versa. While external code switching is the transition of languages from national languages to foreign languages and vice versa.

Most speakers command several varieties of any language they speak, and bilingualism, even multilingualism, is the norm form many people throughout the world rather than unilingual. In other word, people are more likely to choose either one particular language or code when they communicate with others in their daily interaction. Usually code switching is often found in society or a group of bilingual or multilingual people. Based on the phenomenon above, the writer are interested in researching code switching used by society in Baturaja Village. Cause the Baturaja society are classified as heterogeneous community, because composition of Baturaja villagers is not only from the Sasak ethnic as a native but there are migrant ethnic groups such as the Samawa, Mbojo, Bali and Java. Heterogeneous societies have religion, culture, ethnicity, race and education that influence the choice of language used. It does not require the possibility of code switching from one language to another language. The partner said of code switching which focused in this study, namely adults and adults, adults and teenagers, and between teenagers and teenager. 


\section{REVIEW OF LITERATURE}

\section{Sociolinguistic}

Sociolinguistic is a part of linguistic that concerned in language as a social and culture (Sumarsono 2009:3 restated of Trudgill 1974's). This science is a contextual study of variations in the use of public language in a natural communication. The term sociolinguistics itself has been used by Haver C. Curie in an article published in 1952, the title of which is A Projection of Sociolinguistics: The Relationship of Speech to Social Status which contains problems related to the variety of languages a person has with social status in society. Below there are some sociolinguistic insights according to experts:

Abdul Chaer (2004: 2) argues that the essence of sociology is an objective study of humans in society, concerning institutions, and social processes that exist in society. While the notion of linguistics is the field of study of languages or fields of science that take language as the object of study. Thus, it can be said that sociolinguistics is an interdisciplinary field of science that studies language in relation to the use of language in society. Wijana (2006: 7) argues that sociolinguistics is a branch of linguistics that views or places the position of language in its relationship with the user of that language in society. This opinion basically holds to the fact that in human society, life is no longer an individual, but as a social society. Moreover, Nababan said that sociolinguistics is a language study with a social dimension. In sociolinguistics there are also speech events namely the continuation of linguistic interaction in a form of speech involving two speakers and opponents of speech.

Dell Hymes (1972) states that a speech event must fulfill eight components, which if the first letters are combined into an acronym of SPEAKING. The eight components are (lifted from Wardhaugh 1990). S (Setting and scene), P (Participants), E (Ends: purpose and goal), A (Act sequences), K (Key: tone or spirit of act), I (Instrumentalities), N (Norms of interaction on interpretation), G (Genre). Setting and scene; setting relates to the time and place of speech, while the scene refers to the situation of place and time, or the psychological situation of the conversation. Participants are parties involved in the discussion, can be speakers and listeners, greeters and messengers, or senders and recipients of messages, two people who communicate can change roles as speakers or listeners. Ends refers to the purpose of 
discussion. Act sequences refer to the form of speech and content of speech. Key refers to the tone, manner, and spirit in which a message is conveyed. Instrumentalities refer to the language path used, such as the oral pathway, written, by telegraph or telephone. These instrumentalities also refer to the speech code used, such as language, dialect, variety, etc. Norm of interaction and interpretation refers to the norms or rules in interacting. Genre refers to the type of delivery form, such as narration, poetry, proverb, prayer, etc.

\section{Code switching}

Code switching is a transition event from one code to another. According to Maihun Huhulmon (1985: 43) 'code switching' is a change that someone makes from one language to another. For example, speakers using Indonesian switch to using Sasak. Code switching is one aspect of language dependence in multilingual communities. In multilingual society, it is very difficult for an absolute speaker to use only one language. In code switching, each language still tends to support each function and each function according to the context.

Appel limits the code switching as a symptom of switching language usage because of changing circumstances. Hymes (1875:103) says that code switching has become a common term for alternate us of two or more language, varieties of language, or even speech styles.

\section{Society}

According to Soerjono Soekanto, society generally has the following characteristics: Humans who live together at least two people, mix or mingle for quite a long time, gathering humans will create new humans, as a result of living together, communication systems and regulations arise that govern human relations, realize that they are a unit and a system of living together, the system of shared life raises culture because they feel themselves related to each other. 


\section{METHOD}

This research uses sociolinguistic approach and is a field research. This study uses qualitative research. According to Nazir (1988), descriptive qualitative method is a method of examining the status of a group of humans an object, a set of conditions, a system of thought or a class of event in the present.

The techniques of providing data using observation, recording, transcripting data, interviewing, and taking note. The observation method collects preliminary data from the respondent, the unvoled conversation observation technique. The writer does not participate in the conversation and observe the conversation. The writer just listens and observes the informant's language.

This research uses 21 respondents of society from Baturaja, with age background around $18^{\text {th }}$ to $51^{\text {st }}$ year. The composition of respondent not only from Sasak ethnic but there are migrant from Samawa ethnic, Mbojo ethnic, Bali ethnic, and Java ethnic. There are several types of livelihoods of the respondent such as, students, civil servant, traders, doctors, fisherman, entrepreneurship, and teachers.

\section{DISCUSSION}

This section of the study deals with the analysis of data and discussion of the research findings. Types of code switching used (internal and external) and the factor that determine code switching used by society.

\section{Internal Code Switching}

Internal code switching is a code switching that comes from its own language like Indonesia language to Sasak language.

Ana : Bik.....jakq beli sampo

(Aunti.... I want to buy shampoo)

Mahnan : Sampo ape..?

(What shampoo...?)

Ana : Sampo headshoulder..., Bik

(Shampoo headshoulder..., Aunti)

Mahnan : Pire?

(How many?)

Ana : Sekek doang, Bik!

(Only one, Aunti!)

Mahnan : Ne ....Na ..... bener Iza dia ngidam? 
(Here...Na.... is that true Iza craves?)

Ana : Nggih, Bibik!

(Yes, Aunti)

Mahnan : Alhamdulillah, udah berapa bulan perutnya?

(Alhamdulillah, how many months her pregnant?)

Ana : Kurang tahu, Bik. Soalnya dia jarang datang, terakhir dia ke sini dua minggu lalu, dia mau makan rujak buatan kita.

(I don't know, Aunti, because she not often come, the last time she came here two weeks ago, she wanted to eat salad fruit made by me).

Mahnan : $O w w w$

(Owww)

The data show that the conversation occurs between Ana (A) and Mahnan (M) with different age. Ana is 27 years and Mahnan 38 years. Both of speakers are from Sasak ethnic. This conversation is in neighborhood scope and include internal code switching because in this conversation the speaker used Sasak language and switch to Indonesia language.

\section{External Code Switching}

External code switching is instead transfer code from one's own language to foreign language such as Indonesia language to English or preferably. Here the example of data.

Arni : Kapan kita mendaki lagi?

(When will we climb again?)

Diana : Maybe. After earthquake is finish

Arni : Are you sure?

Diana : Yes,,, cause BMKG said there will be earthquake again

Arni : It's just hoax sist

Diana : But BMKG have said

Arni : It's just prediction you know

Diana : But I'm worry worry you know

From the data show that the conversation occurs between two teenagers with the same age background around 19 years to 24 years. But both of them come from different ethnic. Speaker A (Arni) is from Sasakness etnic and speaker B (Diana) from Balinese ethnic. This conversation is type of External code switching cause they speak used Indonesia language and switch in to English language. 


\section{CONCLUSION}

From the result of the analysis, code switching occurs in Batu Raja village in daily communication. The writer found the type and factor that determine code switching used by Baturaja society. The type that used by Baturaja society are internal code switching and external code switching. Internal code switching usually used by old person because they are fluency speak Sasak language and Indonesia language, while external code switching usually used by teenagers.

After analyzing, the writer also found some factors that determine code switching such as first is the speaker the behavior or attitude of the speaker. The second is listener speech partner or listener can cause the code switching. The third is the presence of third person here the presence of third person or other person who does not have the same language background as the language that is used in the communication. The fourth is change of situation. The last factor is discussion topic, when conversation is happened, topic are dominant factor in determining code switching. The most often determine code switching in this study is the presence of third person and the changing of discussion topic.

\section{SUGGESSTION}

This article can be useful for the reader and especially to student who love linguistic.

\section{REFERENCE}

Agus, S. (2006). Pengantar Statistika. Yogyakarta: Graha Ilmu

Appel, Rene, \& Gerad, H. (1976). Sosiolinguistiek. Utrech-Antwerpen: Het spectrum.

Ariyana, G. (2013). A Sociolinguistic in Code Switching on Facebook: Mataram. Bumigora Mataram.

Booij, Kersten \& Verkuyl. (1975). Sociolinguitik: Goals, Approach, and Problems. London: Bastford Ltd.

Chaer, A. (2003). Psikolingugistik Kajian Teoritik. Jakarta: PT. Rineka Cipta

Chaer, A \& Agustina, L. (2010). Sosiolinguistik Perkenalan Awal.Jakarta.: PT. Rineka Cipta

Chaer, A. (2003). Linguistik Umum. Jakarta: Rineka Cipta.

De Saussure. (1966). Course in General Linguistic. New York: MC graw Hill book 
company.

Fishman. (1976). The Relationship between Micro and Macro Sociolinguistic: Study Who Speaks What Language to Whom and When. In Holmes. 15-32.

Gumperz, J.J. (1972) Direction of Sociolinguistic: The Ethnography of Communication. New York: Holt, Rinehart and Winston Inc.

Horton, P.B. \& Hunt, C. (2006). Sosiologi. Jakarta: PT. Erlangga.

Hymes, D. (1875). Foundation of Sociolinguistic. Philadelphia: University of Pensylvania Press.

Mahsun. (2007). Metode Penelitian Bahasa. Jakarta: PT. Raja Grafindo Persada.

Martinet. (1987). Ilmu Bahasa Pengantar. Bandung: PT. Remaja Rosdakarya.

Nazir. (1988). Metode Penelitian. Jakarta: Ghalia Indonesia.

Setiawan. (2006). Pengantar Statistika. Jakarta: Graha Ilmu.

Suktiningsih, W. (2017). Pergeseran Penggunaan Bahasa Sasak di Kalangan Remaja Etnis Sasak. Universitas Marwadewa

Sumarsih. (2014). "Code Switching and Code Mixing in Indonesia: Study in Sociolinguistic". English Language and Literature Studies, Volume 4 No. 1. pp.77-92.

Treudgill, \& Petter. (1974). Sociolinguistic: An Introduction. Hrmondworth: Penguin Book Ltd.

Kridalaksana, \& Harimurti. (2011). Kamus Linguistik. Jakarta: Gramedia Pustaka Umum

Yuliana, W. (2013). An analysis of Code Switching in the Novel 9 Summers 10 Autums. Padang: Andalas University. 